\title{
DETEKSI POTENSI FITOTOKSISITAS ALUMINIUM PADA TANAH TOKSIK DI LAHAN REKLAMASI KAWASAN HUTAN DENGAN BIOASSAY SORGUM
}

\author{
Detection of Potential Aluminum Phytotoxicity on Toxic Land with Sorgum Bioassay \\ Muhammad Abdul Latif Al-Ansori ${ }^{*}$, Yadi Setiadi², Basuki Wasis ${ }^{2}$
}

(Diterima Juni 2017/Disetujui Agustus 2017)

\begin{abstract}
Aluminium (Al) phosphotoxicity is the most common constraint in acidic soil. Information on potential Al phytotoxicity is required in revegetation planning, monitoring of this information is generally done through laboratory analysis procedure in the laboratory that requires high cost and time. The purposes of this study were to test the method of quick detection of Al phytotoxicity with sorghum bioassay. Soil samples taken from post-gold mining land in Bolaang Mongondow Regency of North Sulawesi Province were analyzed for soil physical and chemical properties then planted with numbu varieties of sorghum with complete randomized design, sorghum growth performance response and its correlation with soluble $\mathrm{Al}$ and $\mathrm{pH}$ were analyzed and then the symptoms occured from Al-toxicity on sorghum were observed. Sorgum responds to Al-toxicity by showing symptoms of shortening and thickening of the roots and stunted growth performance. Sorghum growth performance has significant negative correlation with soluble Al concentration on soil, and soil acidity showed a stronger correlation. Al-phytotoxicity symptom in sorghum at pH below 3.7 begins to be clearly visible and easily observed, this distinct appearance difference makes sorghum potential to be used as bioindicator to detect Al-phytotoxicity on the soil.
\end{abstract}

Keywords: Aluminium phytotoxicity, sorghum, post-mining revegetation

\section{PENDAHULUAN}

Kegiatan pertambangan terbuka (open pit mining) pada ekosistem hutan memiliki dampak yang signifikan terhadap kualitas dan fungsi ekosistem hutan. Dalam prosesnya, kegiatan pertambangan membuka tutupan vegetasi, mengubah karakter tanah beserta komunitas mikrobanya, dan selanjutnya menyebabkan sejumlah besar dampak buruk bagi lingkungan (Sheoran et al. 2010). Oleh sebab itu, setiap perusahaan yang melakukan kegiatan penambangan dibebani kewajiban untuk melakukan reklamasi lahan paska tambang sesuai rencana reklamasinya sebagaimana diatur dalam Peraturan Menteri ESDM nomor 07 tahun 2014.

Revegetasi lahan paska tambang merupakan bagian dari proses reklamasi yang secara efektif dapat mengembalikan kualitas dan fungsi ekosistem hutan. Proses ini mencakup pengelolaan semua jenis gangguan fisik, kimia dan biologi tanah seperti $\mathrm{pH}$ tanah, kesuburan, komunitas mikroba dan berbagai siklus hara tanah yang membuat lahan yang terdegradasi menjadi tidak produktif (Sheoran et al. 2010). Tantangan yang sering dihadapi dalam proses revegetasi lahan paska tambang adalah karakter tanah yang tidak mendukung pertumbuhan tanaman. Ketersediaan logam berat terutama unsur aluminium (Al) pada lahan paska

\footnotetext{
${ }^{1}$ Mahasiswa Pascasarjana PS. Silvikultur Tropika,

Fakultas Kehutanan IPB

* Penulis korespondensi:

e-mail: alanshary.latif@gmail.com

${ }^{2}$ Staff Pengajar Dept. Silvikultur, Fakultas Kehutanan IPB
}

tambang merupakan faktor pembatas utama yang sering ditemui. Hal ini terjadi karena tanah telah mengalami penyingkapan dan oksidasi selama kegiatan penambangan berlangsung.

Kelarutan $\mathrm{Al}$ yang tinggi dapat menghambat pemanjangan dan pembelahan sel tanaman, menghalangi sistem transportasi ion tertentu pada membran plasma, dan menurunkan aktivitas ATPase pada membran (Kochian 1995). Kelarutan Al pada konsentrasi tinggi menjadi kendala revegetasi yang membuat tanaman memiliki daya hidup yang rendah, kerdil dan sering menunjukan gejala-gejala penyakit nonpatogenik akibat keracunan Al. Setiadi (2013) mengemukakan bahwa $\mathrm{Al}$ dapat mematikan tanaman jika tersedia pada konsentrasi lebih dari 2,75 me/100g. Untuk menunjang keberhasilan revegetasi dibutuhkan input teknologi yang tepat sasaran dan didukung oleh informasi mengenai ketersediaan $\mathrm{Al}$ pada tanah.

Umumnya informasi potensi fitotoksisitas $\mathrm{Al}$ tanah diperoleh dengan cara menganalisis kandungan $\mathrm{Al}$ tanah di laboratorium. Analisis tersebut membutuhkan waktu dan biaya yang tidak sedikit. Metode deteksi fitotoksisitas Al yang lebih cepat dan murah perlu dikembangkan agar penanganannya menjadi lebih efisien. Bioassay dengan sorgum sebagai bioindikator potensi fitotoksisitas $\mathrm{Al}$ adalah gagasan yang diajukan dalam penelitian ini. Sorgum dinilai memiliki potensi untuk digunakan sebagai bioindikator penilaian fitotoksisitas mengingat karakternya yang cepat berkecambah dan cepat tumbuh sehingga cepat pula menunjukan respon terhadap fitotoksisitas. Disamping itu, benih sorgum sangat mudah diperoleh dan disimpan. 
Arah penelitian ini adalah untuk menguji metode bioassay sorgum untuk deteksi cepat fitotoksisitas Al. Berdasarkan hal itu penelitian ini bertujuan untuk: (1) menganalisis respon pertumbuhan sorgum terhadap bioavailabilitas $\mathrm{Al}$; (2) Menganalisis korelasi antara bioavailabilitas $\mathrm{Al}$ dan kemasaman tanah terhadap pertumbuhan sorgum; (3) Menentukan tingkat kemasaman yang memunculkan fitotoksisitas Al bagi sorgum.

\section{METODE PENELITIAN}

\section{Tempat dan Waktu Penelitian}

Penelitian ini di lakukan di lahan paska tambang emas di Kabupaten Bolaang Mongondow Provinsi Sulawesi Utara dan rumah kaca Departemen Silvikultur Fakultas Kehutanan dari September 2015 hingga Agustus 2016.

\section{Prosedur Karakterisasi Sifat Fisik dan Kimia Tanah}

\section{Pemilihan lokasi pengambilan sampel tanah}

Lokasi pengambilan sampel tanah berupa lahan reklamasi kawasan hutan paska tambang emas di Sulawesi Utara. Sebanyak 21 sampel tanah dari 21 blok tanam dipilih berdasarkan keragaman pertumbuhan tanaman revegetasi dan kandungan Al-dd di tanahnya.

Informasi mengenai sumber deposit dan sejarah penyingkapan tanah diperoleh dengan mengacu pada peta operasi tambang dan keterangan dari pendamping lapangan dari pihak perusahaan.

\section{Koleksi dan analisis sampel tanah}

Sampel tanah diambil dengan menggunakan bor tanah, sampel tanah diambil sebanyak \pm 1500 gram, sebanyak 1000 gram disiapkan untuk menjadi media tanam sorgum dan 500 gram untuk dianalisis sifat fisik dan kimianya. Sampel tanah dikering anginkan dalam suhu ruangan sebelum dikemas dalam kantung plastik berlabel, pengeringan tanah dilakukan untuk mencegah perubahan sifat tanah selama penyimpanan sebelum dianalisis di lab. Analisis sifat fisik dan kimia tanah dilakukan di Laboratorium Kesuburan Tanah Departemen Manajemen Sumberdaya Lahan Fakultas Pertanian IPB, parameter yang diukur adalah pH, Al-dd, tekstur, $\mathrm{N}$ total, P-bray dan $\mathrm{K}$.

\section{Pengujian respon pertumbuhan sorgum terhadap Al-dd}

Respon tumbuh yang diamati adalah panjang akar, panjang pucuk, panjang total dan berat kering total sorgum. Faktor peubah adalah konsentrasi Al-dd pada 22 media tanam. Unit percobaan berupa 66 wadah, yaitu 21 tanah tambang beserta 1 tanah normal sebagai kontrol dengan masing-masing 3 ulangan, dalam 1 wadah terdapat 4 tanaman sorgum sebagai anak unit percobaan.

\section{Penyiapan media tanam, penanaman dan perawatan}

Media tanam berupa 21 tanah dari lokasi tambang dan 1 tanah normal dari Arboretum Fakultas Kehutanan IPB sebagai kontrol. Media tanam disiapkan dengan memasukan masing-masing jenis tanah ke dalam 66 wadah tanpa campuran pupuk kompos atau media tanam lain. Tanah disaring terlebih dahulu agar terbebas dari kerikil selanjutnya ditempatkan pada wadah-wadah berukuran $7 \mathrm{~cm}$ x $7 \mathrm{~cm}$ x $1,5 \mathrm{~cm}$ dan ditempatkan di rumah kaca dengan suhu dan kelembaban siang rata-rata $36{ }^{\circ} \mathrm{C}$ dan $55 \%$, dengan posisi yang diacak untuk meminimalisir faktor perbedaan pencahayaan dalam rumah kaca.

Penanaman dan pengecambahan benih sorgum dilakukan langsung di dalam wadah bermedia tanah uji dengan menabur 4 benih pada masing-masing wadah. Benih sorgum yang digunakan adalah benih sorgum varietas numbu yang segar baru panen dari tanaman induknya yang dibudidayakan oleh laboratorium mikoriza PAU IPB yang memiliki daya kecambah awal $100 \%$ setelah diuji dengan metode Uji diatas Kertas (UDK) yang dimodifikasi.

Perawatan tanaman dilakukan dengan penyiraman rutin untuk mempertahankan kadar air media tanam pada kapasitas lapang, yaitu dengan menyiram tiap media tanam hingga air hampir menggenang permukaan media tanam setiap sore hari. Fungisida diberikan pada awal penanaman benih.

\section{Pengukuran pertumbuhan dan daya hidup tanaman}

Variabel pertumbuhan yang diukur adalah berat kering total (BKT), panjang akar, panjang pucuk dan panjang total. BKT tanaman diukur setelah tanaman dipanen, yaitu 1 bulan setelah tanam. Pengukuran berat kering tanaman dilakukan dengan menggunakan timbangan digital setelah tanaman dioven dengan suhu $80{ }^{\circ} \mathrm{C}$ hingga dicapai berat kering yang konstan (Hairiah et al. 2007). Panjang akar, panjang pucuk dan panjang total tanaman diukur menggunakan penggaris setelah tanaman dipanen juga.

\section{Analisis Data}

Analysis of Variance (ANOVA) satu arah dilakukan untuk data BKT, panjang akar, panjang pucuk dan panjang total. Dilanjutkan dengan uji Beda Nyata Terkecil (BNT) Fisher pada nilai $\mathrm{p} \leq 0,05$. Uji korelasi Pearson dilakukan terhadap data Al-dd dan $\mathrm{pH}$ sebagai faktor untuk mengukur kekuatan hubungannya dengan parameter pertumbuhan sorgum.

\section{HASIL DAN PEMBAHASAN}

\section{Analisis Tanah}

Hasil analisis sifat kimia tanah parameter Al-dd, pH dan KTK tanah yang disajikan pada Tabel 1 menunjukan penurunan KTK tanah pada kemasaman dan konsentrasi Al-dd tinggi. Nilai KTK pada perlakuan $\mathrm{V}$ hanya 7,95 me/100g, menurun sebesar 21,21 me/100g dari kontrol, hal ini menunjukan bahwa tanah di lokasi penelitian merupakan tipe liat kaolinit (1:1).

Ma (1999) menyimpulkan bahwa nilai KTK pada tanah tipe liat kaolinit sangat bergantung pada ukuran partikel dan nilai pH. Hardjowigeno (2007) juga menyebutkan bahwa pada mineral liat kaolinit masingmasing unit mineral saling mengikat dengan unit lain dengan kuat oleh ikatan H. Substitusi isomorfik sedikit 
atau tidak ada sehingga kandungan muatan negatif atau KTK rendah, muatan negatif hanya ada pada patahanpatahan kristal atau akibat disosiasi $\mathrm{H}$ bila $\mathrm{pH}$ naik. Karena itu KTK mineral ini meningkat bila $\mathrm{pH}$ naik (muatan tergantung $\mathrm{pH}$ ).

\section{Respon Tumbuh Sorgum}

Respon pertumbuhan sorgum terhadap paparan Aldd pada 22 konsentrasi yang berbeda disajikan pada Tabel 1 dan Tabel 2. Tabel 1 menyajikan respon tersebut dengan hasil uji beda nyata, dan Tabel 2 menyajikan kekuatan korelasinya.

Hasil uji beda nyata menunjukan bahwa pada media dengan konsentrasi Al-dd yang berbeda menghasilkan pertumbuhan sorgum yang berbeda nyata. Perlakuan U menghasilkan respon tumbuh sorgum yang paling buruk pada setiap parameter tumbuh (panjang akar, panjang pucuk dan panjang total) meskipun konsentrasi Al-dd pada media U bukanlah yang tertinggi, sorgum yang ditanam pada media tanah dengan Al-dd sebesar 21,84 ini sama sekali tidak berkecambah dan tidak tumbuh. Respon tumbuh sorgum pada perlakuan konsentrasi Aldd tertinggi (ID media tanam V) memang bukan yang terendah, tetapi secara statistik tidak berbeda nyata dengan perlakuan $U$ yang merupakan perlakuan yang menghasilkan pertumbuhan sorgum terendah. Marschner (1995) menyatakan bahwa secara umum telah disepakati bahwa konsentrasi tinggi aluminium merupakan faktor kunci dari stres keasaman tanah.

Koefisien korelasi pada setiap parameter respon terhadap faktor konsentrasi Al-dd memiliki nilai negatif, yang menunjukan hubungan penghambatan antara konsentrasi Al-dd dengan pertumbuhan sorgum, yaitu semakin tinggi konsentrasi Al-dd pada tanah akan mengurangi nilai parameter-parameter respon tumbuh

Tabel 1 Hasil analisis kimia tanah dan uji beda nyata pengaruh media terhadap pertumbuhan sorgum

\begin{tabular}{|c|c|c|c|c|c|c|}
\hline \multirow{2}{*}{$\begin{array}{c}\text { ID } \\
\text { media } \\
\text { tanam }\end{array}$} & \multirow{2}{*}{$\begin{array}{c}\text { Kandungan } \\
\text { Al-dd } \\
\text { (me/100 g) }\end{array}$} & \multirow[b]{2}{*}{$\mathrm{pH}$} & \multirow[b]{2}{*}{$\begin{array}{c}\text { KTK } \\
(\mathrm{me} / 100 \mathrm{~g})\end{array}$} & \multicolumn{3}{|c|}{ Rata-rata } \\
\hline & & & & $\begin{array}{c}\text { Panjang } \\
\text { Akar }(\mathrm{cm})\end{array}$ & $\begin{array}{l}\text { Panjang Pucuk } \\
(\mathrm{cm})\end{array}$ & $\begin{array}{l}\text { Panjang } \\
\text { Total }(\mathrm{cm})\end{array}$ \\
\hline $\mathrm{A}$ & 0 & 5,3 & 29,16 & $4,40^{\text {ef }}$ & $21,37^{\mathrm{abc}}$ & $25,77^{\text {abcde }}$ \\
\hline B & 0,39 & 3,2 & 23,68 & $1,17^{\text {ghi }}$ & $5,78^{\text {fghi }}$ & $6,94^{\mathrm{hij}}$ \\
\hline $\mathrm{C}$ & 1,56 & 4,4 & 14,9 & $3,69^{\mathrm{fgh}}$ & $15,66^{\text {cde }}$ & $19,34^{\operatorname{def}}$ \\
\hline D & 2,15 & 4,3 & 18,34 & $5,94^{\text {bcdef }}$ & $22,32^{\mathrm{ab}}$ & $28,26^{\mathrm{abcd}}$ \\
\hline $\mathrm{E}$ & 3,51 & 4,1 & 18,34 & $4,01^{\mathrm{fg}}$ & $7,41^{\text {fgh }}$ & $11,42^{\mathrm{gh}}$ \\
\hline $\mathrm{F}$ & 4,10 & 3,1 & 23,68 & $0,00^{\mathrm{i}}$ & $0,35^{\mathrm{i}}$ & $0,35^{\mathrm{j}}$ \\
\hline G & 5,27 & 3,7 & 11,08 & $7,93^{\text {abcd }}$ & $10,1^{\text {efg }}$ & $18,03^{\mathrm{fg}}$ \\
\hline $\mathrm{H}$ & 6,24 & 3,9 & 9,14 & $4,85^{\mathrm{def}}$ & $8,34^{\text {fgh }}$ & $13,19^{\mathrm{gh}}$ \\
\hline I & 7,22 & 4,3 & 19,1 & $8,17^{\mathrm{abc}}$ & $26,28^{\mathrm{a}}$ & $34,45^{\mathrm{ab}}$ \\
\hline $\mathrm{J}$ & 8,39 & 4 & 14,52 & $10,27^{\mathrm{a}}$ & $22,45^{\mathrm{ab}}$ & $32,72^{a b c}$ \\
\hline $\mathrm{K}$ & 9,56 & 3,8 & 18,72 & $7,32^{\text {abcde }}$ & $11,55^{\mathrm{def}}$ & $18,87^{\mathrm{efg}}$ \\
\hline $\mathrm{L}$ & 10,53 & 3,9 & 16,04 & $5,07^{\text {cdef }}$ & $7,04^{\text {fgh }}$ & $12,11^{\text {ghi }}$ \\
\hline M & 11,70 & 3,3 & 13,37 & $0,63^{\mathrm{hi}}$ & $3,04^{\mathrm{hi}}$ & $3,68^{\mathrm{ij}}$ \\
\hline $\mathrm{N}$ & 12,87 & 3,1 & 25,98 & $0,35^{\mathrm{i}}$ & $2,62^{\mathrm{hi}}$ & $2,97^{\mathrm{j}}$ \\
\hline $\mathrm{O}$ & 13,46 & 3,9 & 20,25 & $7,33^{\text {abcde }}$ & $15,13^{\text {cde }}$ & $22,46^{\text {efg }}$ \\
\hline $\mathrm{P}$ & 14,24 & 3,4 & 13,75 & $0,47^{\mathrm{i}}$ & $3,06^{\mathrm{hi}}$ & $3,52^{\mathrm{ij}}$ \\
\hline Q & 16,38 & 3,5 & 26,74 & $0,52^{\mathrm{hi}}$ & $4,81^{\text {ghi }}$ & $5,33^{\text {hij }}$ \\
\hline $\mathrm{R}$ & 17,94 & 4 & 27,89 & $9,04^{\mathrm{ab}}$ & $17,51^{\text {bcd }}$ & $26,55^{\mathrm{cdf}}$ \\
\hline $\mathrm{S}$ & 18,92 & 3,2 & 21,39 & $0,59^{\mathrm{hi}}$ & $2,33^{\mathrm{hi}}$ & $2,92^{\mathrm{j}}$ \\
\hline $\mathrm{T}$ & 19,31 & 4 & 16,81 & $8,15^{a b c}$ & $26,92^{\mathrm{a}}$ & $35,07^{\mathrm{a}}$ \\
\hline $\mathrm{U}$ & 21,84 & 3,7 & 14,9 & $0^{\mathrm{i}}$ & $0^{\mathrm{i}}$ & $0^{\mathrm{j}}$ \\
\hline V & 25,16 & 3,8 & 7,95 & $2,78^{\text {fghi }}$ & $4,92^{\text {ghi }}$ & $7,69^{\text {hij }}$ \\
\hline
\end{tabular}

Angka-angka pada masing-masing kolom yang tidak diikuti dengan huruf superscript yang sama menunjukan perbedaan yang nyata pada tingkat kepercayaan $95 \%$

Tabel 3 Korelasi faktor kemasaman dan konsentrasi A1-dd terhadap parameter-parameter performa tumbuh sorgum

\begin{tabular}{llccc}
\hline \multirow{2}{*}{ Faktor } & Parameter respon & $\begin{array}{c}\text { Koefisien } \\
\text { Korelasi (r) }\end{array}$ & R2 (\%) & P-value \\
\hline \multirow{4}{*}{ Konsentrasi Al-dd } & $-0,527$ & 27,8 & 0,000 \\
& Panjang total & $-0,517$ & 26,7 & 0,000 \\
& Panjang pucuk & $-0,451$ & 20,3 & 0,000 \\
& Panjang akar & $-0,336$ & 11,3 & 0,006 \\
\hline \multirow{4}{*}{$\mathrm{pH}$} & BKT & 0,705 & 49,7 & 0,000 \\
& Panjang total & 0,719 & 51,7 & 0,000 \\
& Panjang pucuk & 0,537 & 28,8 & 0,000 \\
& Panjang akar & 0,485 & 23,5 & 0,000 \\
\hline
\end{tabular}


sorgum, sedangkan hubungan pertumbuhan sorgum terhadap faktor $\mathrm{pH}$ memiliki nilai korelasi positif. Panjang total dan panjang pucuk menunjukan korelasi yang paling kuat dibandingkan parameter lainnya. Korelasi faktor kemasaman terhadap pertumbuhan sorgum lebih kuat daripada faktor konsentrasi Al-dd.. Foto yang menunjukan respon negatif pertumbuhan sorgum terhadap semakin tingginya kandungan Al-dd media disajikan pada Gambar 1. Grafik titik pencar antar faktor-faktor ini disajikan pada Gambar 2.

Korelasi nilai parameter panjang total sorgum dengan konsentrasi Al-dd menghasilkan persamaan dengan koefisien determinasi $\left(\mathrm{R}^{2}\right)$ yang terbesar dibandngkan parameter respon tumbuh lainnya, yaitu $27,8 \%$, yang berarti keragaman data panjang pucuk sorgum dijelaskan atau dipengaruhi oleh keragaman konsentrasi Al-dd sebesar 27,8\% sedangkan sisanya dijelaskan oleh faktor lain.

Faktor pH menunjukan keeratan hubungan yang lebih kuat terhadap performa tumbuh sorgum dibandingkan dengan faktor Al. 51,7\% dari keragaman panjang pucuk sorgum dijelaskan oleh keragaman kemasaman media, sementara faktor $\mathrm{Al}$ hanya menjelaskan $26,7 \%$ saja.

Keeratan hubungan antara respon tumbuh sorgum dengan Al-dd yang ditunjukan oleh koefisien determinasi memperlihatkan hubungan yang cukup erat. Faktor yang dapat mempengaruhi pertumbuhan sorgum selain konsentrasi Al-dd dalam penelitian ini cukup banyak, tanah-tanah yang menjadi media tanam sorgum dalam penelitian ini memiliki karakter yang tidak seragam, tanah-tanah media yang diambil secara purposive sampling ini memiliki sifat fisik dan kimia yang beragam.

Diantara banyaknya variabel lain yang mungkin mempengaruhi respon tumbuh sorgum, Al-dd sendiri mampu mempengaruhi atau menjelaskan $27,8 \%$ keragaman respon panjang total sorgum, ini menunjukan bahwa Al-dd merupakan faktor yang cukup dominan dalam menghambat pertumbuhan sorgum.

Banyak penelitian menunjukan bahwa toksisitas Al adalah faktor pembatas pertumbuhan yang penting pada

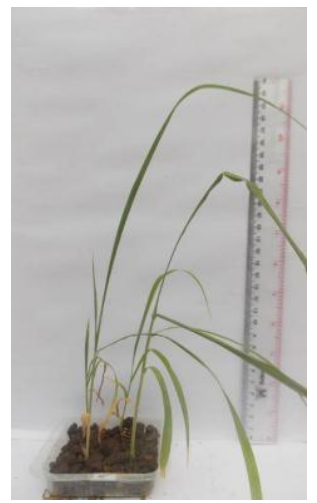

A

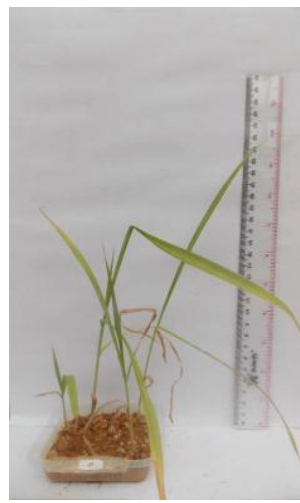

$\mathrm{J}$

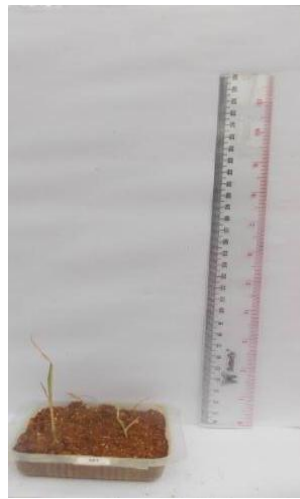

$\mathrm{M}$

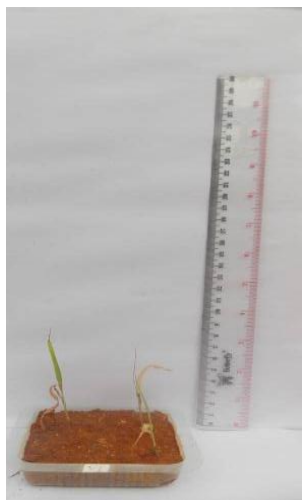

$\mathrm{V}$

Gambar 1 Performa tumbuh sorgum umur 30 hari setelah tanam pada media dengan kandungan Al-dd rendah ke Al-dd tinggi dari kiri ke kanan
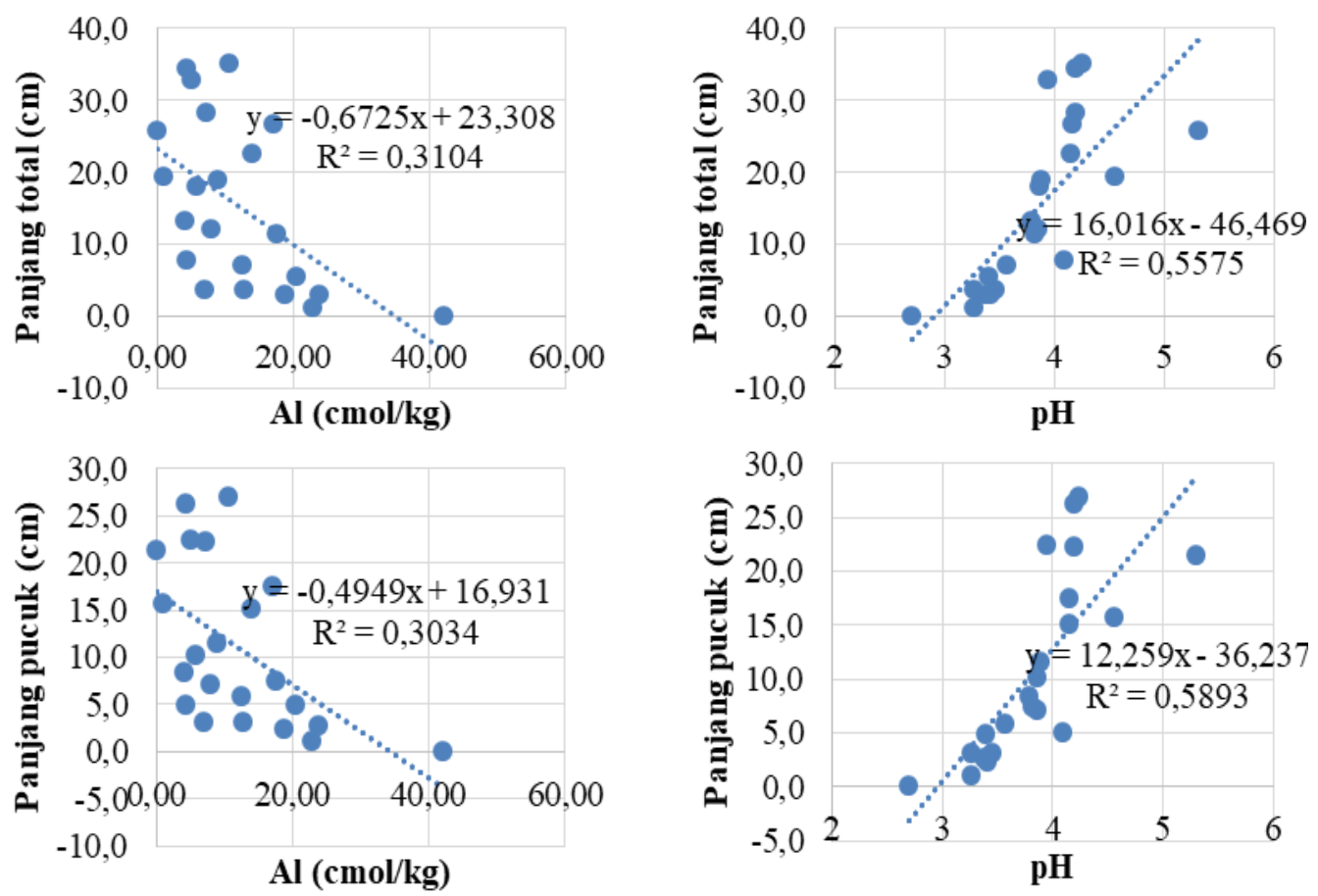

Gambar 2 Grafik scatter plot hubungan negatif konsentrasi Al dengan parameter tumbuh sorgum 
tanah asam. Al mengganggu pembelahan sel pada akar dan akar lateral, meningkatkan kekakuan dinding sel dengan menghubungkan silang pektin, mengurangi replikasi DNA dengan meningkatkan kekakuan heliks ganda DNA, memperbaiki fosfor dalam bentuk yang tidak tersedia di tanah dan pada permukaan akar, menurun. Respirasi akar, mengganggu aktivitas enzim yang mengatur fosforilasi gula dan pengendapan polisakarida dinding sel, dan pengambilan, pengangkutan, dan juga penggunaan beberapa nutrisi penting $(\mathrm{Ca}, \mathrm{Mg}, \mathrm{K}, \mathrm{P}$ dan $\mathrm{Fe})$. Kelebihan $\mathrm{Al}$ juga dilaporkan dapat menginduksi defisiensi besi $(\mathrm{Fe})$ pada padi (Oryza sativa L.), sorgum dan gandum. Al hadir di semua tanah, namun toksisitas Al hanya terwujud dalam kondisi asam, di mana bentuk fitotoksik $\mathrm{Al}^{3+}$ mendominasi. (G Rout et al. 2001)

Respon sorgum terhadap toksisitas $\mathrm{Al}$ terutama tampak pada performa tumbuh akar, setiap sorgum yang ditanam pada $\mathrm{pH}$ dibawah 3,7 dalam penelitian ini menunjukan gangguan yang parah terhadap pertumbuhan akar. Gejala awal yang tampak pada tanaman yang keracunan $\mathrm{Al}$ adalah tidak berkembangnya sistim perakaran yaitu pemendekan dan pembesaran jaringanan akar sebagai akibat penghambatan perpanjangan sel. Hal ini menyebabkan terhambatnya penyerapan unsur hara, terjadinya penggabungan Al dengan dinding sel dan penghambatan pembelahan sel (Harjadi dan Yahya, 1988; Matsumoto et al. 1992). Anira (2014) melaporkan gejala toksisitas Al pada tanaman Bridelia monoica terlihat pada ujung akarnya yang mengeriting (curling). Kochian et al (2005), Munyinda et al (2008) dan Rangel et al (2007) pada studi serupa mengenai jelai, gandum dan kacangkacangan, menunjukkan bahwa peningkatan toksisitas Al menyebabkan penurunan pertumbuhan akar.

Pada tanaman dengan pertumbuhan akar terhambat, $\mathrm{Al}$ ditemukan pada inti dan dinding set. Pada inti sel Al berasosiasi dengan DNA sehingga menghentikan proses pembelahan inti sel pada meristem akar, sedangkan pada dinding sel penghambatan terjadi karena $\mathrm{Al}$ mengganti kedudukan $\mathrm{Ca}$ pada lamela tengah (Marschner, 1995). Al mempunyai afinitas yang tinggi terhadap biomolekul berfosfat, misalnya fosfolipid yang menyusun membran. Pengikatan Al pada fosfolipid akan menyebabkan berubahnya struktur membran sehingga menjadi tidak berfungsi dengan baik dan akhimya menyebabkan kerusakan membran (Wagatsuma dan Koneko, 1997).

\section{Tingkat Kemasaman yang Memunculkan Fitotoksisitas Al}

Aktifitas Al pada tanah sangat dipengaruhi oleh kemasaman tanah (Foy 1974). Al umumnya terdapat di tanah dalam bentuk oksida yang tidak larut, yaitu $\mathrm{Al}(\mathrm{OH})_{3}$, pada $\mathrm{pH}$ netral. Jika tanah menjadi lebih asam (kurang dari 5,5), maka bentuk fitotoksik $\mathrm{Al}\left(\mathrm{Al}(\mathrm{OH})^{2+}\right.$ dan $\mathrm{Al}^{3+}$ ) akan dilepaskan dari larutan tanah (Zhang et al. 2007). Fitotoksisitas Al yang parah pada sorgum dalam penelitian ini terjadi pada suasana tanah masam dengan $\mathrm{pH}$ dibawah 3,7. Grafik respon panjang akar sorgum pada masing-masing level $\mathrm{pH}$ disajikan pada gambar 3.

Umumnya, Al mengacaukan pembelahan sel di ujung akar dan akar lateral, meningkatkan kekakuan dinding sel dengan menyilangkan sambungan pektin, mengurangi replikasi DNA dengan meningkatkan kekakuan rantai helix ganda DNA, mengfiksasi fosfor menjadi bentuk kurang tersedia pada tanah dan padan permukaan akar, menurun respirasi akar, serta mengganggu aktivitas enzim yang mengatur fosforilasi gula dan pengendapan polisakarida dinding sel (Foy 1992).

Penampilan sorgum yang ditanam selama 30 hari di media tanah masam dengan $\mathrm{pH}$ dibawah 3,7 sangat jelas terlihat tidak bisa tumbuh normal jika dibandingkan dengan yang ditanam di media dengan $\mathrm{pH}$ tanah diatas 3,7 bahkan secara kasat mata. Perbedaan penampilan yang sangat mudah diamati ini menjadikan sorgum sangat baik untuk dijadikan indikator untuk deteksi cepat potensi fitotoksistas $\mathrm{Al}$ pada tanah masam.

\section{SIMPULAN}

Sorgum merespon aktivitas Al-dd dengan dengan menunjukan gejala penebalan dan pemendekan akar
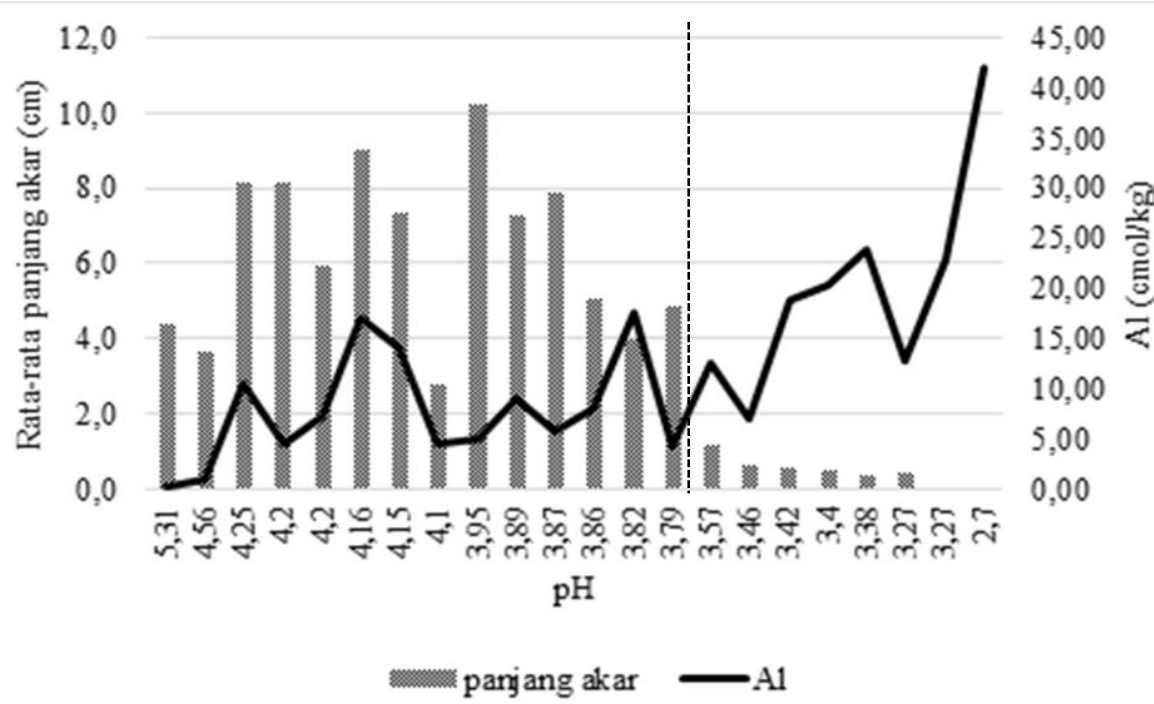

Gambar 3 Grafik batas kemasaman yang menyebabkan penghambatan pertumbuhan akar 
serta performa tumbuh yang kerdil. Pertumbuhan sorgum berkorelasi negatif yang cukup kuat dengan konsentrasi Al-dd pada tanah, semakin tinggi konsentrasi $\mathrm{Al}$ pada tanah cenderung menghasilkan pertumbuhan sorgum yang lebih kecil, respon pertumbuhan sorgum yang terburuk terjadi pada ID perlakuan U dengan $\mathrm{pH}$ 2,7 dan konsentrasi Al-dd 21,84 me/100 g. Kemasaman memiliki korelasi yang lebih kuat daripada Al-dd terhadap pertumbuhan sorgum.

Gejala fitotoksisitas Al pada sorgum pada $\mathrm{pH}$ dibawah 3,7 mulai jelas dan mudah diamati. Perbedaan penampilan yang sangat jelas ini menunjukan bahwa sorgum cukup potensial untuk digunakan sebagai bioindikator untuk mendeteksi potensi fitotoksistas $\mathrm{Al}$ pada tanah.

\section{DAFTAR PUSTAKA}

Anira FC. 2014. Deteksi dini keracunan aluminium tanaman Bridelia monoica Merr. pada tanah pasca tambang batu bara PT. Jorong Barutama Greston Kalimantan Selatan. [Skripsi]. Bogor(ID): Institut Pertanian Bogor.

Foy CD. 1974. Effect of aluminium on plant growth, in: Carson E.W. (Ed.), The Plant Root and its Environment, Virginia: Charlottesville Univ. Press

Foy CD.1992. Soil chemical factors limiting plant root growth, in: Hatfield J.L., Stewart B.A. (Eds.), Advances in Soil Sciences: Limitations to Plant Root Growth, Springer Verlag. 19 :97-149.

Hairiah K, Ekadinata A, Sari RR, Rahayu S. 2011. Pengukuran Cadangan Karbon dari Tingkat Lahan ke Bentang Lahan Edisi ke-2. Bogor (ID): World Agroforestry Center - ICRAF.

Harjadi SS, Yahya S. 1988. Fisiologi Stres Lingkungan. PAU Bioteknologi. Institut Pertanian Bogor. Bogor.

Hardjowigeno S. 2007. Ilmu Tanah. Jakarta: Akademika Pressindo.

Kochian LV. 1995. Cellular mechanisms of aluminum toxicity and resistance in plants. Annu Rev Plant Physiol Plant Mol Biol 46: 237-260
Kochian LV, Piñferos MA, Hoekenga OA. 2005. The physiology, genetics and molecular biology of plant aluminum resistance and toxicity. Plant Soil. 274: 175-195.

Ma C, Eggleton RA. 1999. Cation Exchange Capacity Of Kaolinite. Clays and Clay Minerals 47(2): 174180.

Marschner P, Asher JS, Graham RD. 1991. Effect of manganese-reducing rhizosphere bacteria on the growth of Gaeumannomyces graminis var, tritici and on manganese uptake by wheat \{Triticum aestivum L.). Biol. Fertil. Soils 12: 33-38.

Marschner H. 1995. Mineral Nutrition of Higher Plants. $2^{\text {nd }}$. New York: Academic Press.

Matsumoto Y, Yamamoto M, Kasai. 1992. Change of some properties of the plasma membrane enriched fraction of barley roots related to aluminium stress, membrane associated ATP-ase, aluminium and calcium. Soil Sci. Plant Nutri. 38: 411-419.

Munyinda K, Tembo L, Lungu DM, Masuwa J. 2008. Evaluating for aluminium tolerance in sweet sorghum varieties. Cereal Research Communications.UNZA.

Rangel AF, Rao MI, Horst WJ. 2007. Spacial aluminium sensitivity of root apices of common bean genotypes with contrasting aluminium resistance. Journal of Experimental Botany. 58(14): 3895-3904.

Rout G, Samantaray S, Das P. 2001. Aluminium toxicity in plants: a review. Agronomie, EDP Sciences. 21 (1): 3-21.

Setiadi Y. 2013. Post Mining Restoration Notes: Pembenahan Lahan Pasca Tambang. (tidak dipublikasikan).

Sheoran V, Sheoran AS, Poonia P. 2010. Soil Reclamation of Abandoned Mine Land by Revegetation [ulasan]. International $J$ of Soil, Sediment and Water. 3(2):10-13. Tersedia pada: http://scholarworks.umass.edu/intljssw.

Wagatsuma T, dan Kaneko M. 1997. Hight toxicity ofthe hydroxy aluminium polymer ions to plants roots. Soil. Sci. Plant Nutri. 23: 56-67. 